\title{
Acute respiratory distress syndrome in renal transplant patients with pneumonia
}

\author{
Ventsislava Pencheva $^{1}$, Daniela Petrova ${ }^{1}$, Diyan Genov ${ }^{2}$, Ognian Georgiev $^{1}$ \\ ${ }^{1}$ Department of Propedeutic of Internal Diseases, UMHAT “Alexandrovska”, Medical University, Sofia, Bulgaria \\ ${ }^{2}$ Clinic of Nephrology and Transplantation, UMHAT “Alexandrovska”, Medical University, Sofia, Bulgaria

\section{Email address} \\ pencheva.bg@abv.bg (V. Pencheva),ssn@multicom.bg (D. Petrova),dian.genov@abv.bg (D. Genov), \\ Ogeorgiev@hotmail.com (O. Georgiev)
}

\section{To cite this article:}

Ventsislava Pencheva, Daniela Petrova, Diyan Genov, Ognian Georgiev. Acute Respiratory Distress Syndrome in Renal Transplant Patients with Pneumonia. Science Journal of Clinical Medicine. Vol. 3, No. 5, 2014, pp. 98-103. doi: 10.11648/j.sjcm.20140305.14

\begin{abstract}
Objective: To establish the frequency of Acute Respiratory Distress Syndrome in kidney transplant patients with pneumonia and to define the risk factors associated with its development. Material and Methods: 81 kidney transplant patients hospitalized with pneumonia for the period of three years were studied. All the recipients were observed for the development of Acute Respiratory Distress Syndrome. Different noninvasive and invasive diagnostic tests were used. Results: 15 of the patients with pneumonia developed ARDS. The factors associated with increased risk for the development of Acute Respiratory Distress Syndrome included pneumonia in 1-6 month after transplantation, increased level of $\mathrm{C}$ - reactive protein, Cytomegalovirus-infection, bilateral lung infiltrates and failure of initial antibiotic therapy. Conclusions: The risk factors can be used to identify patients with pneumonia at increased risk for development of Acute Respiratory Distress Syndrome. Strict monitoring of high-risk patients can reduce the morbidity and mortality after renal transplantation.
\end{abstract}

Keywords: Recipient, Transplantation, Pneumonia, ARDS

\section{Introduction}

Acute respiratory failure is one of the most common complications in patients with pulmonary infiltrates and suppressed immune system. It is usually associated with high mortality, and it is a main reason for admission to the intensive care unit of these patients $[1,2]$.

Acute Respiratory Distress Syndrome (ARDS) is a fast progressing form of acute respiratory failure, usually characterized by hypoxemia and a noncardiogenic pulmonary edema. The syndrome is associated with severe damaging of the alveolar-capillary membrane that has a partially clear pathological mechanism. Roentgenological changes occur in both lungs. One of the main causes of ARDS development after kidney transplantation is pulmonary infections [3]. The treatment of ARDS requires the patient to be admitted to an intensive care unit, and to be ventilator supported with non-invasive or invasive mechanical ventilation [4 - 8]. The development of ARDS has a high mortality rate. Within the general population that rate stands at $50 \%$, while in kidney transplant patients with
ARDS it may reach $100 \%[9,10]$.

The aim of this study is to evaluate the frequency of ARDS in kidney transplant patients with pneumonia, and to define the risk factors related to its development.

\section{Material and Methods}

\subsection{Patients}

Table 1. Demographic data

\begin{tabular}{ll}
\hline Age years & $40.59 \pm 12.4(18-61)$ \\
-Male & $53(65.4 \%)$ \\
-Female & $28(34.6 \%)$ \\
Dialysis before & $33.25 \pm 30.898$ \\
transplantation (months) & $26(32.1 \%)$ \\
-Living related donor & $33(40.7 \%)$ \\
-Living unrelated donor & $22(27.2 \%)$ \\
-Deceased donor & $18(22.2 \%)$ \\
Complicated early & \\
postoperative period & \\
\hline
\end{tabular}

81 kidney transplant recipients with pneumonia were enrolled in the study. All patients provided written informed 
consent to participate. The protocols conformed to the guidelines of the 1975 Helsinki Declaration. Patients younger than 18 years of age, patients with concomitant chronic respiratory diseases (COPD, asthma, emphysema, chronic bronchitis or active tuberculosis) and all types of neoplasm were excluded from the study. All enrolled kidney transplant recipients were monitored for the development of ARDS during the treatment period. The diagnosis of ARDS was based on the Berlin definition [11]. All recipients received combination of two or three drugs used for immunosuppressive therapy prior to admission to the hospital. Basic demographic data are shown in Table 1. $52(64.2 \%)$ of the recipients were with hypoxemia at the time of hospital admission. There were no patients diagnosed with ARDS at this time.

\subsection{Testing Procedures}

Medical history and physical examination were performed in all of the cases. Hematological and biochemical blood analysis, microbiological tests of sputum, blood and bronchoalveolar lavage were performed. Electrocardiography, spirometry and arterial blood gases analysis, pulse oximetry, posteroanterior radiography of the lungs and heart, echocardiography were performed in all patients. High resolution computer tomography of the thorax (HRCT) was done in $24(29.6 \%)$ cases. The indications of HRCT are 1) high clinical suspicion of pulmonary infection with normal or dubious chest radiography and 2) exclusion of alternative diagnoses. Depending on the localization of roentgenological changes, pneumonia is divided into unilateral - left or right and bilateral - affected both lungs.

Fiberoptic bronchoscopy (FOB) was performed in 28 $(34.6 \%)$ cases. The indications for FOB include microbiological diagnosis in patients with no sputum production or lack of improvement within 3 days of initial antibiotic therapy.

Immunological methods, including enzyme-linked immunospot (ELISPOT), enzyme-linked immunosorbent assay (ELISA) for the analyses of Cytomegalovirus (CMV) IgM and IgG anti-bodies, and the Real Time polymerase chain reaction amplification for Cytomegalovirus detection, were used.

\subsection{Statistical Analysis}

We used SPSS version 14 to analyze the data. A variational analysis of the quantitative variables was used, as well as the Chi-square test and Fisher's exact test, the method of Kolmogorov-Smirnov and the method of Mann-Whitney. Evaluation of the quantitative parameters was done with a ROC-analysis. Logistic regression analyses, Cox-regression with the formation of curves of survivability in accordance with the Kaplan-Meier method were used. A value of $\mathrm{P} \leq 0.05$ was considered statistically significant.

\section{Results}

Throughout the course of the study, 15 of the patients affected by pneumonia developed ARDS. There is a statistically significant difference between the groups with ARDS, and without ARDS in the postoperative period of the pneumonia onset $(\mathrm{p}=0.012)$. In the early postoperative period (0-1 month) two $(33.33 \%)$ out of 6 patients developed ARDS. In the 1 to 6 months period - 11 (28.95\%) out of 38 pneumonia patients developed ARDS. In the late postoperative period only $2(5.41 \%)$ of all 37 pneumonia patients developed ARDS.

The analysis of the laboratory results of the patients in ARDS and non - ARDS group are shown in Table 2.

Table 2. Laboratory parameters in non-ARDS and ARDS patients.

\begin{tabular}{|c|c|c|c|}
\hline $\begin{array}{l}\text { Laboratory } \\
\text { parameter }\end{array}$ & $\begin{array}{l}\text { Mean } \pm \text { SD } \\
\text { non- ARDS } \\
(n=66)\end{array}$ & $\begin{array}{l}\text { Mean } \pm \text { SD } \\
\text { ARDS }(n=15)\end{array}$ & $\mathbf{P}$ \\
\hline CRP mg/l & $31.26 \pm 46.45$ & $107.23 \pm 98.69$ & $0.020 *$ \\
\hline $\begin{array}{l}\text { Erythrocytes } \\
10^{\wedge} 12 / \mathrm{L}\end{array}$ & $4.27 \pm 0.58$ & $4.02 \pm 0.44$ & 0.260 \\
\hline Leukocytes $\times 10^{\wedge} 9 / \mathrm{L}$ & $8.84 \pm 3.50$ & $9.87 \pm 5.41$ & 0.998 \\
\hline Neutrophils $10^{\wedge} 9 / 1$ & $7.59 \pm 3.47$ & $16.29 \pm 21.62$ & 0.897 \\
\hline Lymphocytes $10^{\wedge} 9 / 1$ & $2.03 \pm 1.32$ & $2.44 \pm 4.92$ & 0.364 \\
\hline Monocytes $10^{\wedge} 9 / 1$ & $0.53 \pm 0.39$ & $1.31 \pm 2.35$ & 0.478 \\
\hline Eosinophils $10^{\wedge} 9 / 1$ & $0.18 \pm 0.48$ & $0.12 \pm 0.16$ & 0.154 \\
\hline Basophils $10^{\wedge} 9 / 1$ & $1.02 \pm 0.15$ & $1.03 \pm 0.16$ & 0.986 \\
\hline $\begin{array}{l}\text { Thrombocytes } \\
10^{\wedge} 9 / \mathrm{L}\end{array}$ & $242.88 \pm 80.73$ & $270.96 \pm 141.29$ & 0.642 \\
\hline Hemoglobin $\mathrm{g} / \mathrm{L}$ & $116.93 \pm 24.50$ & $113.08 \pm 18.57$ & 0.780 \\
\hline Creatinine $\mathrm{mkmol} / \mathrm{l}$ & $219.99 \pm 183.90$ & $235.64 \pm 184.51$ & 0.762 \\
\hline Fibrinogen $\mathrm{g} / 1$ & $4.67 \pm 1.45$ & $6.26 \pm 1.75$ & 0.503 \\
\hline BUN mmol/L & $7.25 \pm 5.42$ & $7.33 \pm 5.83$ & 0.975 \\
\hline
\end{tabular}

* - p-value with statistic significant difference

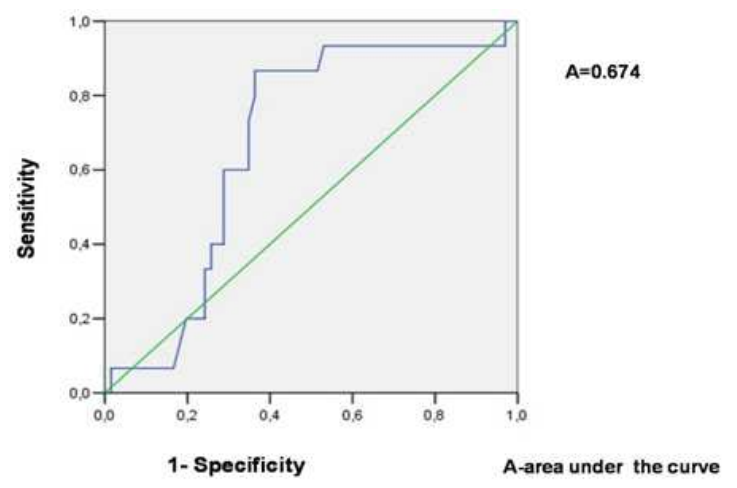

Figure 1. ROC curve of CRP for development of ARDS

The difference in the mean levels of C-reactive protein (CRP) between these groups was significant $(p=0.020)$. The heightened values of CRP (normal values $<5 \mathrm{mg} / \mathrm{L}$ ) increase the probability of developing ARDS. The calculated ROC- curve is shown in Figure 1. The area under the curve is 0.674 (95\% CI $0.539-0.808), \mathrm{p}=0.037$. There is no statistically significant difference regarding other laboratory parameters.

The analysis of the arterial blood gases of the patients in ARDS and non - ARDS group at the time of hospital 
admission is shown in Table 3 . There is not statistically significant difference between arterial blood gases in the two groups. At the time of hospital admission 36 (54.5\%) of the patients in the non-ARDS group had hypoxemia versus 12 $(80 \%)$ of the patients with ARDS $(\mathrm{p}=0.086)$.

Table 3. Arterial blood gases analysis in non-ARDS and ARDS patients at the time of hospital admission.

\begin{tabular}{|c|c|c|c|}
\hline & Non-ARDS $(n=66)$ & $\operatorname{ARDS}(n=15)$ & $\mathbf{P}$ \\
\hline $\mathrm{pH}$ & $7.39(7.30-7.49)$ & $7.40(7.37-7.44)$ & 0.691 \\
\hline $\begin{array}{l}\mathrm{PaO} 2 \\
\mathrm{mmHg}\end{array}$ & $66.53(31.60-106.30)$ & $59.08(46.16-79.50)$ & 0.077 \\
\hline $\begin{array}{l}\mathrm{PaCO} 2 \\
\mathrm{mmHg}\end{array}$ & $34.39(28.7-42.4)$ & $34.36(27.4-44.0)$ & 0.989 \\
\hline $\begin{array}{l}\mathrm{HCO} 3 \\
\mathrm{mEq} / \mathrm{L}\end{array}$ & $23.1(22.1-24.4)$ & $22.2(20.9-24.8)$ & 0.351 \\
\hline $\begin{array}{l}\mathrm{BE} \\
\mathrm{mmol} / \mathrm{L}\end{array}$ & $0.57(-5.8-8.2)$ & $-0.42(-6.0-4.3)$ & 0.492 \\
\hline
\end{tabular}

$\mathrm{PaO} 2$ - partial pressure of arterial oxygen; $\mathrm{PaCO} 2$ - partial pressure of arterial carbon dioxide; $\mathrm{HCO} 3$ - arterial blood bicarbonate; $\mathrm{BE}$ - base excess

Figure 2 represents the ROC- curve of the values of the partial pressure of arterial oxygen $(\mathrm{PaO} 2)$. The area under the curve is 0.678 (95\% CI $0.553-0.802), \mathrm{p}=0.032$.

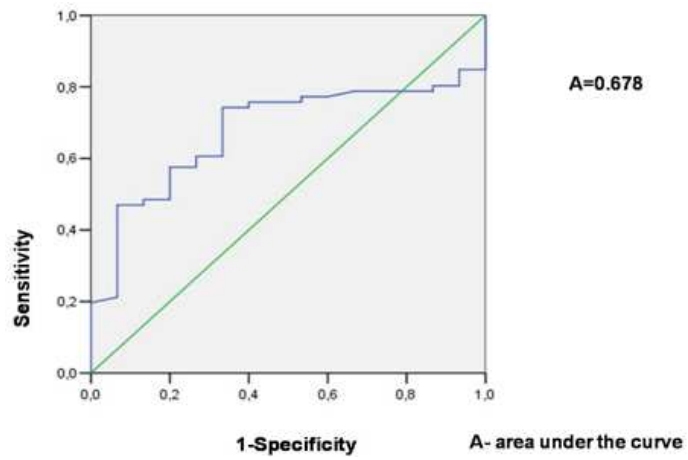

Figure 2. ROC-curve of $\mathrm{PaO} 2 \mathrm{mmHg}$ on the first day.

The analysis of the arterial blood gases of the patients in ARDS and non - ARDS group on the third day of treatment is shown in Table 4. The difference in mean value of $\mathrm{PaO} 2$ between these groups was significant $(p=0.001) .30(46.3 \%)$ of the patients in the non - ARDS group and all $15(100 \%)$ patients in the ARDS - group had hypoxemia $(p<0.001)$.

Table 4. Arterial blood gases analysis in non-ARDS and ARDS patients on third day.

\begin{tabular}{lllll}
\hline & non - ARDS $(\mathbf{n}=66)$ & ARDS $(\mathbf{n}=\mathbf{1 5})$ & P \\
\hline $\mathrm{pH}$ & $7.38(7.34-7.44)$ & $7.37(7.33-7.40)$ & 0.604 \\
$\mathrm{PaO} 2 \mathrm{mmHg}$ & $68.90 \quad(29.20-50.69(33.50-$ & $0.001^{*}$ \\
$\mathrm{PaCO} 2$ & $92.40)$ & $68.20)$ & \\
$\mathrm{mmHg}$ & $36.57(33.20-44.0)$ & $\begin{array}{l}34.77(29.70 \\
42.40)\end{array}$ & 0.066 \\
$\mathrm{HCO} 3$ & $22.4(21.9-24.0)$ & $22.7(21.0-26.8)$ & 0.710 \\
$\mathrm{mEq} / \mathrm{L}$ & $0.14(-2.1-2.7)$ & $-0.86(-2,8-1.2)$ & 0.122 \\
$\mathrm{BE} \mathrm{mmol} / \mathrm{L}$ & & & \\
\hline
\end{tabular}

$\mathrm{PaO} 2$ - partial pressure of arterial oxygen; $\mathrm{PaCO} 2$ - partial pressure of arterial carbon dioxide; $\mathrm{HCO} 3$ - arterial blood bicarbonate; $\mathrm{BE}$ - base excess; * - p - value with statistic significant difference
Figure 3 represents the ROC- curve of the values of $\mathrm{PaO} 2$ on the third day. The area under the curve is $0.786(95 \% \mathrm{CI}$ $0.688-0.884), \mathrm{p}=0.001$.

There is a statistically significant correlation between the development of ARDS and the presence of CMV-infection $(p=0.016)$. Five of the non - ARDS patients and 5 patients with ARDS were with active CMV infection $(9.1 \%$ vs. $33.3 \%)$.

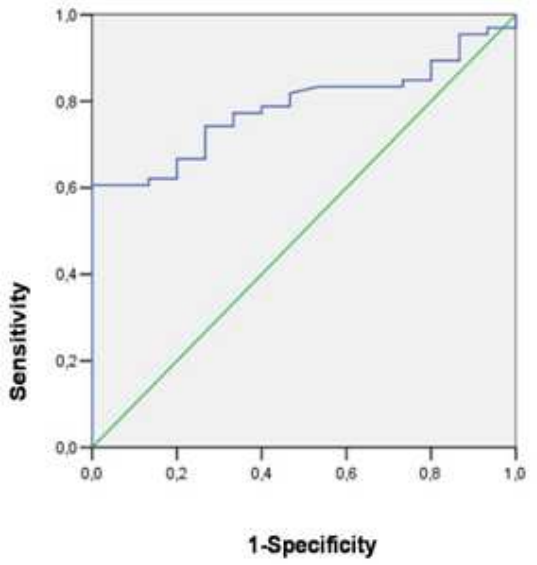

$\mathrm{A}=\mathbf{0 . 7 8 6}$

Figure 3. ROC-curve of $\mathrm{PaO} 2 \mathrm{mmHg}$ on the third day.

The localization of the roentgenological changes at the time of hospital admission differs significantly between ARDS and non - ARDS groups $(\mathrm{p}=0.007)$. There was a predominance of bilateral pneumonia (in $80 \%$ of the cases) in the group of patients who developed ARDS.

In $26(39.39 \%)$ of the patients without ARDS and in 14 $(93.33 \%)$ of the patients with ARDS a change in the antibiotic therapy was needed due to failure of the initial treatment $(\mathrm{p}<0.001)$.

The factors which increase the probability of ARDS development are presented in Table 5.

Table 5. Risk factors for ARDS.

\begin{tabular}{llll}
\hline Factor & OR & $\mathbf{9 5 \%}$ CI & P \\
\hline 1-6 month after transplantation & 7.130 & $1.457-34.895$ & 0.015 \\
Increased level of CRP & 1.471 & $1.021-2.120$ & 0.039 \\
CMV-infection & 7.700 & $1.892-31.344$ & 0.004 \\
$\begin{array}{l}\text { Bilateral lung infiltrates } \\
\begin{array}{l}\text { Failure of initial antibiotic } \\
\text { therapy }\end{array}\end{array}$ & 1.826 & $1.230-2.710$ & 0.003 \\
\hline
\end{tabular}

\section{Discussion}

ARDS often occurs as a complication of pneumonia in kidney transplant patients [12 - 17]. The risk factors for its development include pneumonia in 1-6 month after transplantation, increased level of $\mathrm{C}$ - reactive protein, Cytomegalovirus-infection, bilateral lung infiltrates and failure of initial antibiotic therapy. The pathogenesis of ARDS in these patients is characterized by severe diffuse damage to the alveolar-capillary membrane as a result of 
the infection. Some of the alveoli get filled with liquids, while others collapse and thus there is a sharp disturbance of the ventilation/perfusion ratio with a mosaic nature [18 20]. In a study conducted by Shorr et al. 42190 kidney transplant patients in the USA were observed. 86 of those cases $(0.2 \%)$ developed ARDS, while the estimated incidence of ARDS within the general population was 51 cases per 100000 per year. The incidence of ARDS in kidney transplant patients was significantly higher than that in the general population of the USA $(p<0.05)$. The study showed that factors such as the demographic characteristics, transplantation indications, comorbidity, the antigen compatibility, the CMV-serostatus and the development of transplant rejection do not correlate with the development of ARDS [9]. Sun et al. analyzed 486 patients that had received a kidney from a cadaver, and 21 of them developed ARDS [10]. From our results, during the treatment period, ARDS developed in 15 of the patients with pneumonia (19\%). Our results concerning the incidence of ARDS are significantly higher due to the specificity of patient's cohort included in this study. We calculated the incidence of ARDS only for the patients with pneumonia.

The time of developed pulmonary infections after the operation is crucial to the development of ARDS [21 - 23]. According to our data, the development of pneumonia during the second postoperative period (1 to 6 months) increases the risk of ARDS 7.13 times (OR=7.13; 95\% CI $1.457-34.895 ; \mathrm{P}=0.015)$. Our results come close to those collected by Sun et al. In their study, 18 of the ARDS cases developed within the second or third month of the postoperative period [10]. Gui et al. found that ARDS caused by pneumonia usually occurred 3-6 months after transplantation [24].

The laboratory results of the patients with both pneumonia and development of ARDS do not differ significantly when compared to those collected from the patients without ARDS. The only exception is CRP as it is statistically higher in the group suffering from ARDS $(p<0.05)$. The CRP increased as a result of lung injure and as a systemic inflammatory response [24 - 31]. If the CRP increases with one unit upper than maximum reference level, the risk for developing ARDS increases 1.475 times $(\mathrm{OR}=1.471 ; 95 \%$ CI $1.021-20.120 ; \mathrm{P}=0.039)$. CRP values of $45.95 \mathrm{mg} / \mathrm{L}$ are with both the highest sensitivity $73.3 \%$ and specificity $-65.2 \%$. A more detailed monitoring of the patients is required in CRP values above this point. This will further improve early diagnosis of ARDS.

Hypoxemia at the time of hospital admission increases the risk of ARDS [32, 33]. Values of $\mathrm{PaO} 2$ of $59.70 \mathrm{mmHg}$ are both with the highest sensitivity - 74.2\% and specificity- $66.7 \%$ as a prognostic indicator for ARDS development.

On the third day of treatment, arterial blood gases tests showed a prevalence of hypoxemia in patients who would develop ARDS $(\mathrm{p}<0.001)$. The $\mathrm{PaO} 2$ values of 58.45 $\mathrm{mmHg}$ on the third day of hospitalization can predict with high probability ARDS development (sensitivity- 74.2\%, specificity- $73.3 \%$ ).

There is a correlation between the development of ARDS and the presence of CMV-infection [34 - 38]. The presence of CMV-infection increases the risk for ARDS 7.7 times $(\mathrm{OR}=7.7$; 95\% CI 1.892 - 31.344; $\mathrm{P}=0.004)$. The results come close to those collected by Shorr et al. In their study, $9.1 \%$ of the cases of CMV-serologically negative recipient/ CMV-serologically positive donor developed ARDS [9].

The severity of the lung injury and the localization of the roentgenological changes in pneumonia patients play a certain role in the development of ARDS [39, 40]. The presence of bilateral roentgenological changes with inflammatory character at the time of hospital admission increases the risk of ARDS development 1.826 times $(\mathrm{OR}=1.826 ; 95 \%$ CI $1.826-2.710 ; \mathrm{P}=0.003)$.

The initial antibiotic treatment failure increases the risk of ARDS [41 - 46]. According to our data initial antibiotic failure is associated with 21.538 times $(\mathrm{OR}=21.538 ; 95 \%$ CI 2.669 - 173.784; $\mathrm{P}=0.004)$ higher risk of ARDS development.

\section{Conclusion}

ARDS is one of the main complications of pneumonia in kidney transplant recipients. In our study, risk factors for the development of ARDS are: pneumonia in 1- 6 month after transplantation, increased level of $\mathrm{C}$ - reactive protein, bilateral lung infiltrates, $\mathrm{CMV}$ - infection and failure of initial antibiotic therapy. Recognition of risk factors would help prevention or early treatment of ARDS. That would lead to a general decrease of morbidity and mortality in the group of patients after renal transplantation.

\section{References}

[1] Candan S, Pirat A, Varol G, Torgay A, Zeyneloglu P, Arslan G Respiratory problems in renal transplant recipients admitted to intensive care during long-term follow-up. Transplant Proc 2006, 38 1354-1356.

[2] Canet E., Osman D., Lambert J., Guitton C., Heng A., Argaud L., Klouche K., Mourad G., Legendre C., Timsit J.et al. Acute respiratory failure in kidney transplant recipients a multicenter study. Critical Care 2011, 15(2) R91

[3] Donahoe M. Acute respiratory distress syndrome A clinical review. Pulm Circ 2011;1 192-211

[4] Bello G, De Pascale G, Antonelli M. Noninvasive ventilation for the immunocompromised patient always appropriate? Curr Opin Crit Care. 2012; 18(1) 54-60.

[5] Kothe H., Dalhoff K. Pneumonia in the immunocompromised patient. Eur Respir Mon, 2006, 36, 200-213.

[6] Namendys-Silva SA, Hernández-Garay M, Herrera-Gómez A. Noninvasive ventilation in immunosuppressed patients. Am J Hosp Palliat Care. 2010;27(2) 134-8 
[7] Antonelli M, Conti G, Bufi M, Costa MG, Lappa A, Rocco M, Gasparetto A, Meduri GU. Noninvasive ventilation for treatment of acute respiratory failure in patients under-going solid organ transplantation a randomized trial. JAMA 2000; $2832239-2240$

[8] Garpestad E, Brennan J, Hill NS. Noninvasive ventilation for critical care. CHEST 2007; 132 711-720

[9] Shorr, A; Abbott, KC; Agadoa LY. Acute respiratory distress syndrome after kidney transplantation Epidemiology, risk factors, and outcomes. Critical Care Medicine. 2003; 31 (5) $1325-1330$

[10] Sun Q., Liu Z.-H., Chen J., Ji S., Tang Z., Cheng Z., Ji D., Li L.S. An aggressive systematic strategy for acute respiratory distress syndrome caused by severe pneumonia after renal transplantation. Transplant International, 2006, 19 110-116.

[11] ARDS Definition Task Force, Ranieri VM, Rubenfeld GD, Thompson BT, Ferguson ND, Caldwell E, Fan E, Camporota L, Slutsky AS. Acute respiratory distress syndrome the Berlin Definition. JAMA. 2012;307(23) 2526-33

[12] Bauer T. T., Ewig S., Rodloff A. C., Müller E. E., "Acute respiratory distress syndrome and pneumonia a comprehensive review of clinical data," Clin Infect Dis. 2006; 43 (6) 748-756

[13] Tarun G., Viswanathan S., Karnam A., Abraham G. "Etiology and Outcomes of ARDS in a Rural-Urban Fringe Hospital of South India," Critical Care Research and Practice, vol. 2014, Article ID 181593, 7 pages, 2014

[14] Mandell LA, Bartlett JG, Dowell SF, File TM Jr, Musher DM, Whitney C. Update of practice guidelines for the management of community-acquired pneumonia in immunocompetent adults. Clin Infect Dis 2003; 37 1405-33.

[15] Estenssoro E, Dubin A, Laffaire E, Canales H, Sáenz G, Moseinco M, Pozo M, Gómez A, Baredes N, Jannello G, Osatnik J. Incidence, clinical course, and outcome in 217 patients with acute respiratory distress syndrome. Crit Care Med 2002; 30 2450-6.

[16] Valta P, Uusaro A, Nunes S, Ruokonen E, Takala J. Acute respiratory distress syndrome frequency, clinical course, and costs of care. Crit Care Med 1999; 27 2367-74

[17] Gauthier GM, Safdar N, Klein BS, Andes DR. Blastomycosis in solid organ transplant recipients. Transpl Infect Dis. 2007; $9310-7$.

[18] Bastarache J.A., Blackwell TS. Development of animal models for the acute respiratory distress syndrome. Disease models \& mechanisms, 2009, 2.5-6 218-223.

[19] Matthay MA, Zemans RL.The Acute Respiratory Distress Syndrome Pathogenesis and Treatment. Annu Rev Pathol. 2011; 6 147-163.

[20] Matthay M.A., Ware L.B., Zimmerman G.A. The acute respiratory distress syndrome. J Clin Invest. 2012; 122(8) 2731-2740.

[21] Feltracco P., Carollo C., Barbieri S., Pettenuzzo T., Ori C. Early respiratory complications after liver transplantation World J Gastroenterol. Dec 28, 2013; 19(48) 9271-9281.

[22] Speich R., Bij W. Epidemiology and Management of Infections after Lung Transplantation Clin Infect Dis. 2001; 33 (Supplement 1) S58-S65.
[23] Grim SA, Clark NM Management of infectious complications in solid-organ transplant recipients. Clin Pharmacol 2011; 90 333-342

[24] Gui P.,Luo Z.,Zeng J.,Yan C.,Li F.,Huang Z.,Yang J.,Xiao $\mathrm{H} ., \mathrm{Wu} \mathrm{K}$. Treatment and characteristics of acute respiratory distress syndrome caused by pulmonary infection after renal transplantation. Chinese Journal of Infection Control. 2012-02

[25] Ware LB. Pathophysiology of acute lung injury and the acute respiratory distress syndrome. Semin Respir Crit Care Med. 2006; 27 337-349

[26] Rice TW, Bernard GR. Acute lung injury and the acute respiratory distress syndrome challenges in clinical trial design. Clin Chest Med. 2006; 27 733-754.

[27] Bajwa EK, Khan UA, Januzzi JL, Gong MN, Thompson BT, Christiani DC. Plasma C-reactive protein levels are associated with improved outcome in ARDS. Chest 2009. $136471-480$

[28] Zhang Z, Ni H. C-reactive protein as a predictor of mortality in critically ill patients a meta-analysis and systematic review. Anaesthesia and Intensive Care. 2011; 39(5) 854-861.

[29] Hillas G, Vassilakopoulos T, Plantza P, Rasidakis A, Bakakos P. C-reactive protein and procalcitonin as predictors of survival and septic shock in ventilator-associated pneumonia. European Respiratory Journal. 2010; 35(4) 805-811.

[30] Coelho L, Póvoa P, Almeida E, Fernandes A., Mealha R., Moreira P., Sabino H. Usefulness of C-reactive protein in monitoring the severe community-acquired pneumonia clinical course. Critical Care. 2007; 11 p. R92.

[31] Coelho LM, Salluh JI, Soares M, Bozza FA., Verdeal JCR., Castro- Faria- Neto HC., Silva JRLE., Bozza PT, Povoa P. Patterns of C-reactive protein ratio response in severe community-acquired pneumonia a cohort study. Critical Care. 2012; 16 p. R53.

[32] Mei S., Yao W., Zhu Y., Zhao J. Protection of Pirfenidone against an Early Phase of Oleic Acid-Induced Acute Lung Injury in Rats. J Pharmacol Exp Ther. 2005, 313 (1) 379-88

[33] Gunning K. Pathophysiology of Respiratory Failure and Indications for Respiratory Support. Surgery 2003; 21(3) 72-6

[34] Papazian L, Doddoli C, Chetaille B, Gernez Y, Thirion X, Roch A, Donati Y, Bonnety M, Zandotti C, Thomas P A contributive result of open-lung biopsy improves survival in acute respiratory distress syndrome patients. Crit Care Med 2007, 35(3) 755-762.

[35] Papazian L, Thomas P, Bregeon F, Garbe L, Zandotti C, Saux P, Gaillat F, Drancourt M, Auffray JP, Gouin F Open-lung biopsy in patients with acute respiratory distress syndrome. Anesthesiology 1998, 88(4) 935-944.

[36] Papazian L, Fraisse A, Garbe L, Zandotti C, Thomas P, Saux P, Pierrin G, Gouin F Cytomegalovirus. An unexpected cause of ventilator-associated pneumonia. Anesthesiology $1996,84(2)$ 280-287.

[37] Osawa R. Singh N. Cytomegalovirus infection in critically ill patients a systematic review. Critical Care 2009, 13 R68

[38] Luyt CE, Combes A., Trouillet JL, Nieszkowska A., Chastre J. Virus-induced acute respiratory distress syndrome epidemiology, management and outcome. Presse Med. 2011; 40(12) 561-8 
[39] Kojicic M., Li G., Gajic O. Acute respiratory distress syndrome in patients with Legionella pneumonia. Acta Medica Academica 2011;40(1) 39-44

[40] Aliberti S., Brambilla A., Chalmers JD, Cilloniz C., Ramirez J., Bignamini A., Prina E, Polverino E, Tarsia P, Pesci A, Torres A, Blasi F, Cosentini R. Phenotyping community-acquired pneumonia according to the presence of acute respiratory failure and severe sepsis. Respiratory Research 2014, 1527

[41] Rello J.Importance of appropriate initial antibiotic therapy and de-escalation in the treatment of nosocomial pneumonia Eur Respir Rev 2007; 16 103, 33-39

[42] Depuydt PO, Vandijck DM, Bekaert MA, Decruyenaere JM, Blot SI, Vogelaers DP, Benoit DD. Determinants and impact of multidrug antibiotic resistance in pathogens causing ventilator-associated-pneumonia. Crit Care Med. 2008;12 R142
[43] Kojicic M, Li G, Hanson AC, Lee KM, Thakur L, Vedre J, Ahmed A, Baddour LM, Ryu JH, Gajic O. Risk factors for the development of acute lung injury in patients with infectious pneumonia. Critical Care 2012, 16 R46

[44] Torres A, Ewig S, Lode H, Carlet J. Defining, treating and preventing hospital acquired pneumonia European perspective. Intensive Care Med 2009; 35 9-29.

[45] Mandell LA,Wunderink RG, Anzueto A, Bartlett JG., Campbell GD, Dean NC. Infectious Diseases Society of America/American Thoracic Society Consensus Guidelines on the Management of Community-Acquired Pneumonia in Adults Clin Infect Dis. 2007, 44 (Supplement 2) S27-S72.

[46] Venditti M, Falcone M, Corrao S, Licata G, Serra P. Outcomes of patients hospitalized with community-acquired, health care-associated, and hospital-acquired pneumonia. Ann Intern Med 2009; 150 19-26. 